\title{
Effect of Cytokine Gene Polymorphisms on Eltrombopag Reactivity in Japanese Patients with Immune Thrombocytopenia
}

\author{
Shosaku Nomura' \\ Misao $\mathrm{Abe}^{2}$ \\ Manabu Yamaoka ${ }^{2}$ \\ Tomoki Ito (D)
}

'First Department of Internal Medicine, Kansai Medical University, Hirakata, Osaka, Japan; ${ }^{2}$ Division of Blood Transfusion, Kansai Medical University, Hirakata, Osaka, Japan
Correspondence: Shosaku Nomura First Department of Internal Medicine, Kansai Medical University, 2-5-I Shin-Machi, Hirakata, Osaka, 573-1010, Japan

Tel + 81728042754

$\mathrm{Fax}+8172804204$

Email shosaku-n@mbp.ocn.ne.jp
Background: Immune thrombocytopenic purpura (ITP) is an autoimmune disease characterized by low platelet counts resulting from antiplatelet autoantibodies. Analysis of polymorphisms in cytokine-encoding genes is important for understanding the pathophysiology of ITP and selecting appropriate treatments. We investigated associations between polymorphisms in cytokine-encoding genes and responses to therapy in Japanese patients with ITP.

Methods: The participants in this study comprised 153 patients with ITP and 70 healthy controls. We extracted data on sex, age, platelet counts, bleeding symptoms, and therapeutic responses, including those to prednisolone (PSL) and eltrombopag. Genomic DNA was isolated from peripheral blood and polymorphisms in TNF- $\alpha$, IL-10, TGF- $\beta_{1}$, and IFN- $\gamma$ genes were analyzed using the PCR-SSP method.

Results: Our results showed that the TGF- $\beta_{1}+869 \mathrm{C} / \mathrm{C}$ genotype might be related to ITP in Japanese patients. The IL-10 $-592 \mathrm{C} / \mathrm{C}$ and A/A, $-819 \mathrm{C} / \mathrm{C}$ and T/T, and $-1082,-819,-592$ ATA/ATA genotypes might be associated with reactivity to PSL. Furthermore, the IL-10 $-592 \mathrm{C} / \mathrm{A}-819 \mathrm{C} / \mathrm{T}$ genotypes, IL-10 ACC/ATA genotype, and TGF- $\beta_{1}+869 \mathrm{~T} / \mathrm{T}$ and T/C genotypes might be linked to the response to eltrombopag.

Conclusion: Our results indicate that analysis of polymorphisms in cytokine-encoding genes could aid in understanding PSL and eltrombopag responsiveness in Japanese patients with ITP.

Keywords: ITP, cytokine gene polymorphism, SNP, prednisolone, eltrombopag

\section{Introduction}

Immune thrombocytopenic purpura (ITP) is an autoimmune disease characterized by low platelet counts resulting from antiplatelet autoantibodies. ${ }^{1,2}$ The target of these antibodies is glycoprotein (GP), and anti-GP antibody is produced through actions of autoreactive B and T cells. ${ }^{3}$ In particular, GPIIb/IIIa proteins serve as major target antigens recognized by platelet-reactive $\mathrm{CD}^{+} \mathrm{T}$ cells (Figure 1). ${ }^{4-7}$ Helper T (Th) cells play an important role in the production of this antibody, and Th cells are classified into Th1, Th2, Th3 or Th17 populations based on their cytokine production pattern. ${ }^{7-9}$ The imbalance of Th1/Th2 participates in the production of antibody in ITP, similar to several other autoimmune diseases. ${ }^{3,7}$ Furthermore, regulatory $\mathrm{T}$ cells that regulate Th3 and Th17 are also important. Platelets that bind antiplatelet antibodies are destroyed by reticuloendothelial cells such as monocytes/macrophages in the spleen (Figure 1). ${ }^{1-9}$ Additionally, antiplatelet 


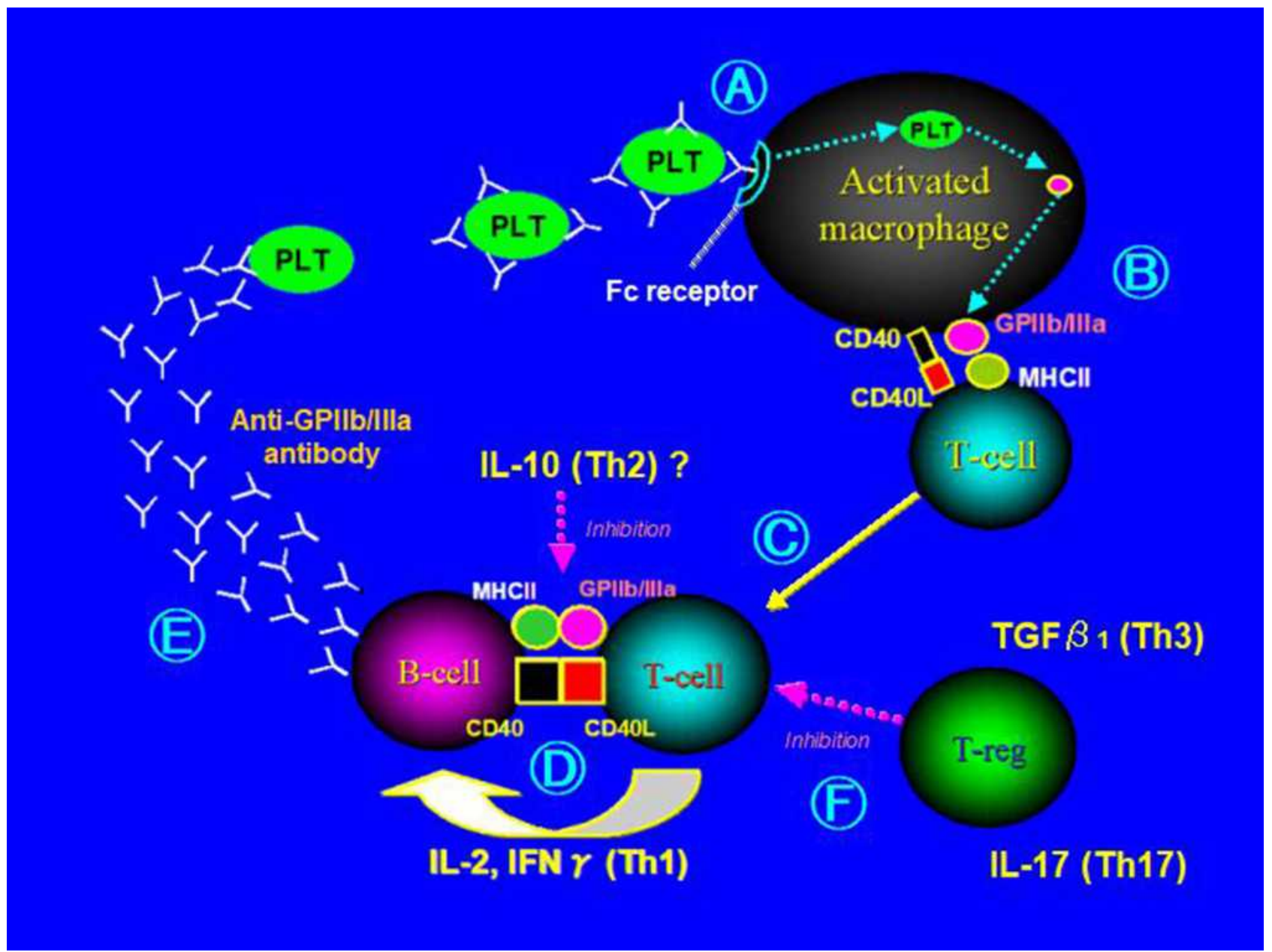

Figure I Presumed mechanism of anti-platelet antibody and platelet destruction in ITP. A. Anti-GPIlb/llla antibody-coated platelets are trapped by the Fc receptors of activated macrophages, following which the platelets are destroyed. B. Activated macrophages present GPIlb/lla-derived antigen to T cells. C. These T cells interact with autoreactive B cells and present the GPIlb/III-derived antigen. D. ThI cytokines such as IL-2 and IFN $\gamma$ promote the activation of B cells. E. Anti-GPIIb/IIla antibodies are produced by activated $\mathrm{B}$ cells. $\mathrm{F}$. T-reg's control is weakened.

Abbreviations: PLT, platelet; CD40L, CD40 ligand; MHCII, major histocompatibility complex II.

autoantibodies induce megakaryocytic maturity disorder and apoptosis, which affects platelet production. ${ }^{9}$

The management of ITP has changed substantially over the last 50 years as understanding of the disease has increased. ${ }^{10,11}$ The standard therapy for ITP comprises corticosteroids. ${ }^{1,2}$ Recently, physiologic therapeutics have been developed as viable alternatives to immunosuppressive therapy. ${ }^{11,12}$ These drugs include thrombopoietin receptor agonists (TRAs) such as romiplostim and eltrombopag. ${ }^{11,13-16}$ TRAs are largely regarded as a thirdline therapy, a position which has remained unchanged in recent years, because they are effective for the improvement of maturation disorders in megakaryocytes. ${ }^{11,12}$ Trials are underway to test several new drugs for their ability to treat ITP. ${ }^{10}$ These drugs contribute to improvements in the prognosis of refractory ITP. ${ }^{17-19}$
It is known that autoimmune diseases have genetic factors. ${ }^{20}$ As previously mentioned, several cytokines (interleukin [IL]-1, IL-2, IL-3 and IL-17) are very important in the pathophysiology of ITP. ${ }^{7-9}$ Therefore, the analysis of polymorphisms in cytokine-encoding genes is important for clinical setting of ITP. ${ }^{21-23}$ The distribution of single-nucleotide polymorphisms varies among different ethnic groups, which is also true specifically for polymorphisms in the cytokine-encoding genes related to ITP. ${ }^{24-38}$ However, there are few reports on the association of cytokine-related polymorphisms with responsiveness to TRAs in Japanese patients with ITP. Therefore, the associations between polymorphisms in cytokine-encoding genes and therapeutic responses to steroids and TRA in Japanese patients with ITP were investigated in the present study. 


\section{Materials and Methods}

\section{Study Design and Participants}

This study was approved by the ethics committee of Kansai Medical University (Osaka, Japan). All participants, or a parent or legal guardian for those under 20 years of age, provided informed consent to participate in this study, which was conducted in accordance with the Declaration of Helsinki. The participants in this study included 153 patients with ITP and 70 healthy controls. Because there are no disease-specific tests for ITP, the diagnosis of ITP was based on excluding other diagnoses. ${ }^{1,2,39}$ We diagnosed ITP according to several international reports. ${ }^{40,41}$

\section{Disease Grade by Assessment of Platelet Count and Bleeding Symptoms}

Disease grade was established according to platelet count (PC) and bleeding symptoms (BS), as follows: grade $0=$ $\mathrm{PC}$ of $81 \times 10^{9} / \mathrm{L}$ to $100 \times 10^{9} / \mathrm{L}$ and $/$ or no BS; grade $1=\mathrm{PC}$ of $51 \times 10^{9} / \mathrm{L}$ to $80 \times 10^{9} / \mathrm{L}$, and/or no BS or purpura $0-2$; grade $2=\mathrm{PC}$ of $31 \times 10^{9} / \mathrm{L}$ to $50 \times 10^{9} / \mathrm{L}$, and/or purpura $3-10$ or mucosal bleeding; grade $3=\mathrm{PC}$ of $11 \times 10^{9} / \mathrm{L}$ to $30 \times 10^{9} / \mathrm{L}$, and/or many purpura or moderate bleeding, with hemoglobin of 7.1-10.0 g/dL; grade $4=\mathrm{PC}, 0$ to $10 \times 10^{9} / \mathrm{L}$, and/or severe or organ bleeding, with hemoglobin of $<7.0 \mathrm{~g} / \mathrm{dL}$.

\section{Therapeutic Responses}

Therapeutic responses to steroid (prednisolone; PSL) and TRA (eltrombopag) were determined using the following criteria after 3 to 12 months of therapy.

PSL start: grade 0, observation grade 1, PSL 5-10 mg/d grade 2, 3, and 4, PSL $0.5-1 \mathrm{mg} / \mathrm{kg}$ of body weight per day.

Eltrombopag start: at the time PSL ineffective. Eltrombopag $12.5-37.5 \mathrm{mg} / \mathrm{d}$.

Responders and nonresponders to PSL or eltrombopag were defined according to the following criteria: (1) No response: $\mathrm{PC}<30 \times 10^{9} / \mathrm{L}$ or the absence of a twofold increase in baseline PC or hemorrhage; (2) partial response: PC between $30 \times 10^{9} / \mathrm{L}$ and $100 \times 10^{9} / \mathrm{L}$, a minimum twofold increase in baseline $\mathrm{PC}$, and the absence of hemorrhage; and (3) complete response: PC $>100 \times 10^{9} / \mathrm{L}$ and the absence of hemorrhage. Patients who met (2) or (3) criteria were considered responders, and those meeting (1) were considered nonresponders.

The effectiveness of PSL was assessed 3 to 6 months after the start of treatment, and effectiveness of eltrombopag was assessed at 12 months. We extracted data on sex, age, PC, BS, and therapeutic responses to PSL and eltrombopag.

\section{Genotyping}

The details have already been reported. ${ }^{42}$ Polymorphisms in the TNF- $\alpha$, TGF- $\beta_{1}$, IL-10, and IFN- $\gamma$ genes were analyzed using a PCR-SSP method using the Cytokine Genotyping Tray (One Lambda Inc., Los Angeles, CA, USA). For the cytokines under investigation, the following polymorphisms were analyzed. For TNF- $\alpha$, the polymorphism in the promoter region at position $-308(\mathrm{G} / \mathrm{A}$; rs1800629); for TGF- $\beta_{1}$, a polymorphism in the coding region, that is, codon $10+869$ (T/C; rs1982073); for IL-10, three polymorphisms in the promoter region, $-1082(\mathrm{G} / \mathrm{A}$; rs1800896), -819 (C/T; rs1800871), and -592 (C/A; rs1800872); for IFN- $\gamma$, a polymorphism in the coding region at position +874 (T/A; rs2430561). DNA fragments corresponding to each cytokine were amplified in accordance with the manufacturer's instructions.

\section{Statistical Analysis}

All statistical analyses were performed using StatFlex v7 software (Artech, Osaka, Japan). Comparison of age between patient and control groups was done using an unpaired $t$-test. Analyses for the studied polymorphisms were done using Pearson's chi-squared test and Fisher's exact probability test. In addition, genotype distribution was analyzed for the studied polymorphisms in two groups of patients with ITP divided by whether treatment (with PSL and/or eltrombopag) had been undertaken. Odds ratios (ORs) with 95\% confidence intervals (CIs) were calculated for disease susceptibility and whether PSL or eltrombopag had been administered (discriminated analysis).

\section{Results}

\section{Patient Characteristics}

Table 1 exhibits the characteristics of ITP and controls. The mean age of the ITP patients was 49.2 \pm 13.1 (range 19-86) years, which was significantly higher than the age of the control groups $(49.2 \pm 13.1, \mathrm{p}=0.00054)$. In terms of sex, the frequency of females was not significantly different between patient and control groups (64.1\% vs $55.7 \%, \mathrm{p}=0.23517)$. Platelet counts ranged from $3 \times 10^{9} / \mathrm{L}$ to $91 \times 10^{9} / \mathrm{L}$, with a mean of $26 \times 10^{9} / \mathrm{L}$ at the initial diagnosis. Additionally, 54 patients (35.3\%) had severe thrombocytopenia. Steroid 
Table I Baseline Characteristics of the Patients with ITP and Healthy Controls

\begin{tabular}{|c|c|c|}
\hline & ITP & Control \\
\hline Number & 153 & 70 \\
\hline Age, years, mean $\pm S D$ & $49.2 \pm 13.1$ & $41.3 \pm 7.8$ \\
\hline Age range & $19-86$ & $24-62$ \\
\hline Gender, F/M & $98 / 55$ & $39 / 31$ \\
\hline First platelet count $\times 10^{9} / \mathrm{L}$ (range) & $26(3-91)$ & \\
\hline $\begin{array}{l}\text { Severe thrombocytopenia*a } \\
\text { No. of cases (\%) }\end{array}$ & $54(35.3)$ & \\
\hline $\begin{array}{l}\text { Bleeding symptoms } \\
\text { No. of cases (\%), Yes } \\
\text { No }\end{array}$ & $\begin{array}{l}94(61.4) \\
59(38.6)\end{array}$ & \\
\hline $\begin{array}{l}\text { Treatment, No. of cases (\%) } \\
\text { Steroid, prednisolone } \\
\text { TRA, eltrombopag }\end{array}$ & $\begin{array}{l}135(88.2) \\
62(40.5)\end{array}$ & \\
\hline $\begin{array}{l}\text { Eradication of } H \text {. pylori } \\
\text { Splenectomy } \\
\text { IVIG } \\
\text { Other, rituximab etc. } \\
\text { Observation }\end{array}$ & $\begin{array}{l}19(12.4) \\
5(3.3) \\
18(11.8) \\
22(14.4) \\
18(11.8)\end{array}$ & \\
\hline $\begin{array}{l}\text { Response to steroid treatment } \\
\text { Responsive, PR \& CR (\%) } \\
\text { Unresponsive (\%) }\end{array}$ & $\begin{array}{l}73 / 135(54.1) \\
62 / 135(45.9)\end{array}$ & \\
\hline $\begin{array}{l}\text { Complications } \\
\text { Cardiovascular, no. of cases (\%) } \\
\text { Diabetes, no. of cases (\%) } \\
\text { Malignancy, no. of cases (\%) }\end{array}$ & $\begin{array}{l}14(9.2) \\
8(5.2) \\
3(2.0)\end{array}$ & \\
\hline
\end{tabular}

Notes: $*^{a}$ Platelet count $<30 \times 10^{9} / \mathrm{L}$. Bold letters/numbers represent statistical significance $(p<0.05)$.

Abbreviations: ITP, immune thrombocytopenia; TRA, thrombopoietin receptor agonist; IVIG, intravenous-immunoglobulin therapy; PR, partial response; CR, complete response.

treatment was given to 135 patients $(88.2 \%) ; 73(54.1 \%)$ were responsive and $62(45.9 \%)$ were unresponsive. Therefore, TRA (eltrombopag) was administered in 62 patients (40.5\%). Eighteen patients (11.8\%) were untreated.

\section{Association of ITP Susceptibility with Polymorphisms in Cytokine-Encoding Genes}

Three of the 153 ITP patients had malignancies. Therefore, we removed these three malignancy cases from the analysis, resulting in 150 ITP patients. We detected significantly lower frequencies of the TGF- $\beta_{1}+869 \mathrm{C} / \mathrm{C}$ genotype in ITP patients compared with controls $\left(9.3 \%\right.$ vs $22.9 \% ; \chi^{2}=$
5.4154; $p=0.01996 ; \mathrm{OR}=0.408)($ Table 2). However, no differences in IFN- $\gamma$, TNF- $\alpha$, or IL-10 genotype frequencies were observed between patients with ITP and controls (Table 2).

\section{Association of Therapeutic Responses in ITP Patients with Polymorphisms in Cytokine-Encoding Genes PSL}

A total of 135 patients with ITP began PSL treatment; 73 patients responded to PSL, whereas 62 did not. Responders had higher frequencies of the IL-10 -819 CC and $-592 \mathrm{CC}$ genotypes than did nonresponders $(26.0 \%$ vs $\left.3.2 \% ; \chi^{2}=9.9532, p=0.00161, \mathrm{OR}=0.124\right)($ Table 3$)$. In contrast, responders had a lower frequency of the IL-10 -819 TT and -592 AA genotypes than did nonresponders $\left(31.5 \%\right.$ vs $\left.59.7 \% ; \chi^{2}=4.1178, p=0.04243, \mathrm{OR}=1.894\right)$ (Table 3).

\section{Eltrombopag}

A total of 62 patients were treated with eltrombopag; 32 responded to eltrombopag, whereas $30 \mathrm{did}$ not. The responders had a higher frequency of the IL-10 -819 C/ $\mathrm{T}$ and $-592 \mathrm{C} / \mathrm{A}$ genotypes than did nonresponders $\left(56.3 \%\right.$ vs $16.7 \% ; \chi^{2}=4.9185, p=0.02657$, OR $=$ 0.296) (Table 4). Additionally, responders had a higher frequency of the TGF- $\beta_{1}$ T/C genotype than did nonresponders $\left(68.7 \%\right.$ vs $13.3 \% ; \chi^{2}=8.4153, p=0.00372$, OR $=0.194)$ (Table 4). In contrast, eltrombopag responders had a lower frequency of the TGF- $\beta_{1}$ T/T genotype than nonresponders $\left(18.8 \%\right.$ vs $70.0 \% ; \chi^{2}=6.6407, p=$ $0.00997, \mathrm{OR}=3.733)($ Table 4$)$.

\section{IL I0 Haplotype Frequencies and Genotypes in Drug Responders and Nonresponders}

The frequency of the IL-10 ACC (-1082, -819, -592) haplotype was significantly increased in PSL and eltrombopag responders (PSL: $44.5 \%$ vs $20.2 \%$; eltrombopag: $31.2 \%$ vs $8.3 \%$ ) (Table 5). In contrast, the IL-10 ATA haplotype was decreased in PSL responders $(52.8 \%$ vs $78.2 \%)$. The frequency of the ACC/ACC genotype was higher $(26.0 \%$ vs $3.2 \%)$, whereas the frequency of the ATA/ATA genotype was lower in PSL responders (31.5\% vs $59.7 \%$ ) (Table 5). In contrast, the frequency of the ACC/ATA genotype was higher in eltrombopag responders than in nonresponders $(56.3 \%$ vs $10.0 \%)$ (Table 5$)$. 
Table 2 Frequencies of Cytokine Gene Polymorphisms in ITP and Normal Controls

\begin{tabular}{|c|c|c|c|c|c|c|c|}
\hline Polymorphism & Genotype & $\begin{array}{c}\text { I50 Patients } \\
\text { N (\%) }\end{array}$ & $\begin{array}{c}70 \text { Controls } \\
\text { N (\%) }\end{array}$ & $\chi^{2}$ Value & $P$ value & OR & $95 \% \mathrm{Cl}$ \\
\hline \multirow[t]{3}{*}{ IL-10-592 } & $\mathrm{C} / \mathrm{C}$ & $24(16.0)$ & $17(24.3)$ & 1.4468 & 0.22904 & 1.518 & $0.767-3.005$ \\
\hline & $\mathrm{A} / \mathrm{A}$ & $66(44.0)$ & $28(40.0)$ & 0.1265 & 0.72206 & 0.909 & $0.538-1.537$ \\
\hline & C/A & $60(40.0)$ & $25(35.7)$ & 0.1656 & 0.68409 & 0.893 & $0.5|7-1.54|$ \\
\hline \multirow[t]{3}{*}{ IL-|0-8I9 } & $\mathrm{C} / \mathrm{C}$ & $24(16.0)$ & $17(24.3)$ & 1.4468 & 0.22904 & 1.518 & $0.767-3.005$ \\
\hline & $\mathrm{T} / \mathrm{T}$ & $66(44.0)$ & $28(40.0)$ & 0.1265 & 0.72206 & 0.909 & $0.538-1.537$ \\
\hline & $\mathrm{C} / \mathrm{T}$ & $60(40.0)$ & $25(35.7)$ & 0.1656 & 0.68409 & 0.893 & $0.5|7-| .54 \mid$ \\
\hline \multirow[t]{3}{*}{ IL-I0-I082 } & $\mathrm{G} / \mathrm{G}$ & $0(0)$ & $0(0)$ & - & - & - & - \\
\hline & $\mathrm{A} / \mathrm{A}$ & I43 (95.3) & $66(94.3)$ & 0.0028 & 0.95755 & 0.989 & $0.658-1.486$ \\
\hline & $\mathrm{G} / \mathrm{A}$ & $7(4.7)$ & $4(5.7)$ & 0.0994 & 0.75253 & 1.224 & $0.347-4.320$ \\
\hline \multirow[t]{3}{*}{ TNF- $\alpha-308$} & $\mathrm{G} / \mathrm{G}$ & 149 (99.3) & $70(100)$ & 0.0011 & 0.97395 & 1.007 & $0.674-1.504$ \\
\hline & $\mathrm{A} / \mathrm{A}$ & $0(0)$ & $0(0)$ & - & - & - & - \\
\hline & $\mathrm{G} / \mathrm{A}$ & I (0.7) & $0(0)$ & 0.4657 & 0.49498 & - & - \\
\hline \multirow[t]{3}{*}{ TGF- $\beta 1+869$} & $\mathrm{~T} / \mathrm{T}$ & $56(37.3)$ & $18(25.7)$ & 1.4827 & 0.22335 & 0.689 & $0.377-1.258$ \\
\hline & $\mathrm{C} / \mathrm{C}$ & $14(9.3)$ & $16(22.9)$ & 5.4154 & 0.01996 & 0.408 & $0.189-0.883$ \\
\hline & $\mathrm{T} / \mathrm{C}$ & $80(53.4)$ & $36(51.4)$ & 0.0216 & 0.88315 & 0.964 & $0.594-1.566$ \\
\hline \multirow[t]{3}{*}{ IFN- $\gamma+874$} & $\mathrm{~T} / \mathrm{T}$ & 7 (4.7) & $4(5.7)$ & 0.0994 & 0.75253 & 1.224 & $0.347-4.320$ \\
\hline & $\mathrm{A} / \mathrm{A}$ & $|2|(80.6)$ & $55(78.6)$ & 0.0146 & 0.90378 & 0.974 & $0.636-1.492$ \\
\hline & T/A & $22(14.7)$ & II (I5.7) & 0.0303 & 0.86189 & I.07| & $0.492-2.331$ \\
\hline
\end{tabular}

Note: Bold letters/numbers represent statistical significance $(p<0.05)$.

Abbreviations: $\mathrm{N}$, absolute number; OR, odds ratio; Cl, confidence interval; TNF, tumor necrosis factor; TGF, transforming growth factor; IL-I0, interleukin-I0; IFN, interferon.

Table 3 Distribution of Cytokine Genotypes in Prednisolone (PSL) Responder and Nonresponder Patients with ITP

\begin{tabular}{|c|c|c|c|c|c|c|c|}
\hline Polymorphism & Genotype & $\begin{array}{l}\text { PSL-res. } \\
73 \text { Patients } \\
\text { N (\%) }\end{array}$ & $\begin{array}{c}\text { PSL-non. } \\
62 \text { Patients } \\
\text { N (\%) }\end{array}$ & $\chi^{2}$ Value & $P$ value & OR & $95 \% \mathrm{Cl}$ \\
\hline \multirow[t]{3}{*}{ IL-I0-592 } & $\mathrm{C} / \mathrm{C}$ & $19(26.0)$ & $2(3.2)$ & 9.9532 & 0.00161 & 0.124 & $0.028-0.553$ \\
\hline & A/A & $23(31.5)$ & 37 (59.7) & 4.1178 & 0.04243 & 1.894 & $1.018-3.524$ \\
\hline & $\mathrm{C} / \mathrm{A}$ & $31(42.5)$ & $23(37.1)$ & 0.1732 & 0.67730 & 0.874 & $0.462-1.65 \mid$ \\
\hline \multirow[t]{3}{*}{ IL- $10-819$} & $\mathrm{C} / \mathrm{C}$ & $19(26.0)$ & $2(3.2)$ & 9.9532 & 0.00161 & 0.124 & $0.028-0.553$ \\
\hline & $\mathbf{T} / \mathrm{T}$ & $23(31.5)$ & $10(59.7)$ & 4.1178 & 0.04243 & 1.894 & $1.018-3.524$ \\
\hline & $\mathrm{C} / \mathrm{T}$ & $31(42.5)$ & II (37.I) & 0.1732 & 0.67730 & 0.874 & $0.462-1.65 \mid$ \\
\hline \multirow[t]{3}{*}{ IL-I0-I082 } & G/G & $0(0)$ & $0(0)$ & - & - & - & - \\
\hline & $\mathrm{A} / \mathrm{A}$ & $69(94.5)$ & $60(96.8)$ & 0.00091 & 0.92399 & 1.024 & $0.631-1.661$ \\
\hline & $\mathrm{G} / \mathrm{A}$ & $4(5.5)$ & $2(3.2)$ & 0.3675 & 0.54437 & 0.589 & $0.104-3.323$ \\
\hline \multirow[t]{3}{*}{ TNF- $\alpha-308$} & G/G & $73(100)$ & 61 (98.4) & 0.0044 & 0.94704 & 0.984 & $0.609-1.590$ \\
\hline & $\mathrm{A} / \mathrm{A}$ & $0(0)$ & $0(0)$ & - & - & - & - \\
\hline & $\mathrm{G} / \mathrm{A}$ & $0(0)$ & I (I.6) & 1.1673 & 0.28000 & - & - \\
\hline \multirow[t]{3}{*}{ TGF- $\beta$ I +869 } & $\mathrm{T} / \mathrm{T}$ & $23(31.5)$ & $27(43.6)$ & 0.9528 & $0.3290 \mathrm{I}$ & 1.382 & $0.721-2.650$ \\
\hline & $\mathrm{C} / \mathrm{C}$ & $5(6.8)$ & $9(14.5)$ & $1.714 \mid$ & 0.19051 & 2.119 & $0.688-6.524$ \\
\hline & $\mathrm{T} / \mathrm{C}$ & $45(61.7)$ & $26(4 I .9)$ & 1.6468 & 0.19942 & 0.680 & $0.378-1.225$ \\
\hline \multirow[t]{3}{*}{$\mathrm{IFN}-\gamma+874$} & $T / T$ & $4(5.5)$ & I (I.6) & 1.3094 & 0.25251 & 0.294 & $0.036-2.391$ \\
\hline & $\mathrm{A} / \mathrm{A}$ & $58(79.5)$ & $52(83.9)$ & 0.0442 & 0.83354 & 1.056 & $0.637-1.749$ \\
\hline & T/A & II (I5.0) & $9(14.5)$ & 0.0060 & 0.93820 & 0.963 & $0.375-2.475$ \\
\hline
\end{tabular}

Note: Bold letters/numbers represent statistical significance $(p<0.05)$.

Abbreviations: PSL-res., prednisolone responder; PSL-non., prednisolone nonresponder; other abbreviations: see Table 2. 
Table 4 Distribution of Cytokine Genotypes in Eltrombopag Responder and Nonresponder Patients with ITP

\begin{tabular}{|c|c|c|c|c|c|c|c|}
\hline Polymorphism & Genotype & $\begin{array}{c}\text { Elt-res. } \\
32 \text { Patients } \\
\text { N (\%) }\end{array}$ & $\begin{array}{c}\text { Elt-non. } \\
30 \text { Patients } \\
\text { N (\%) }\end{array}$ & $\chi^{2}$ Value & P value & OR & $95 \% \mathrm{Cl}$ \\
\hline \multirow[t]{3}{*}{ IL-10-592 } & $\mathrm{C} / \mathrm{C}$ & I (3.I) & I (3.3) & 0.7381 & 0.96421 & 1.067 & $0.064-17.820$ \\
\hline & $\mathrm{A} / \mathrm{A}$ & $13(40.6)$ & $24(80.0)$ & 2.5376 & 0.11122 & 1.970 & $0.855-4.533$ \\
\hline & C/A & $18(56.3)$ & 5 (16.7) & 4.9185 & 0.02657 & 0.296 & $0.098-0.898$ \\
\hline \multirow[t]{3}{*}{ IL-I0-8I9 } & $\mathrm{C} / \mathrm{C}$ & I (3.I) & I (3.3) & 0.7381 & 0.96421 & 1.067 & $0.064-17.820$ \\
\hline & $\mathrm{T} / \mathrm{T}$ & $13(40.6)$ & $24(80.0)$ & 2.5376 & 0.111122 & 1.970 & $0.855-4.533$ \\
\hline & $C / T$ & $18(56.3)$ & 5 (16.7) & 4.9185 & 0.02657 & 0.296 & $0.098-0.898$ \\
\hline \multirow[t]{3}{*}{ IL-I0-I082 } & $\mathrm{G} / \mathrm{G}$ & $0(0)$ & $0(0)$ & - & - & - & - \\
\hline & $\mathrm{A} / \mathrm{A}$ & $32(100)$ & $28(93.3)$ & 0.0362 & 0.84913 & 0.933 & $0.458-1.900$ \\
\hline & $\mathrm{G} / \mathrm{A}$ & $0(0)$ & $2(6.7)$ & 2.0645 & 0.15080 & - & - \\
\hline \multirow[t]{3}{*}{ TNF- $\alpha-308$} & $\mathrm{G} / \mathrm{G}$ & $32(100)$ & $29(96.7)$ & 0.0088 & 0.92521 & 0.967 & $0.476-1.961$ \\
\hline & $\mathrm{A} / \mathrm{A}$ & $0(0)$ & $0(0)$ & - & - & - & - \\
\hline & $\mathrm{G} / \mathrm{A}$ & $0(0)$ & I (3.3) & 1.0489 & 0.49212 & - & - \\
\hline \multirow[t]{3}{*}{ TGF- $\beta$ I +869 } & $\mathbf{T} / \mathbf{T}$ & $6(18.8)$ & $21(70.0)$ & 6.6407 & 0.00997 & 3.733 & $1.326-10.510$ \\
\hline & $\mathrm{C} / \mathrm{C}$ & $4(12.5)$ & $5(16.7)$ & 0.1616 & 0.68772 & 1.333 & $0.328-5.422$ \\
\hline & $\mathbf{T} / \mathbf{C}$ & $22(68.7)$ & $4(13.3)$ & 8.4153 & 0.00372 & 0.194 & $0.060-0.629$ \\
\hline \multirow[t]{3}{*}{ IFN- $\gamma+874$} & $T / T$ & $0(0)$ & I (3.3) & 1.0489 & 0.49212 & - & - \\
\hline & $\mathrm{A} / \mathrm{A}$ & $28(87.5)$ & $24(80.0)$ & 0.0566 & 0.81203 & 0.914 & $0.437-1.913$ \\
\hline & T/A & $4(12.5)$ & $5(16.7)$ & 0.1616 & 0.68772 & 1.333 & $0.328-5.422$ \\
\hline
\end{tabular}

Note: Bold letters/numbers represent statistical significance $(p<0.05)$.

Abbreviations: Elt-res., eltrombopag responder; Elt-non., eltrombopag nonresponder; other abbreviations: see Table 2.

\section{Discussion}

Cellular immunity and cytokine-related responses are very important in the pathophysiology of ITP. ${ }^{1,3,8,12}$ Cytokine gene polymorphisms have been associated with various autoimmune diseases. ${ }^{22,27}$ In the present study, we analyzed the frequencies of some cytokine polymorphisms of

Table 5 Individual IL-10 Haplotype Frequencies and Genotypes in Prednisolone (PSL) or Eltrombopag (Elt) Responders and Nonresponder Patients with ITP

\begin{tabular}{|c|c|c|c|c|c|c|}
\hline $\begin{array}{l}\text { IL-IO } \\
\text { HT \& GT }\end{array}$ & $\begin{array}{c}\text { PSL-res. } \\
73 \text { Patients } \\
\text { N (\%) }\end{array}$ & $\begin{array}{c}\text { PSL-non. } \\
62 \text { Patients } \\
\text { N (\%) }\end{array}$ & $\chi^{2}, \mathbf{p}$ value & $\begin{array}{c}\text { Elt-res. } \\
32 \text { Patients } \\
\text { N (\%) }\end{array}$ & $\begin{array}{c}\text { Elt-non. } \\
30 \text { Patients } \\
\text { N (\%) }\end{array}$ & $\chi^{2}, \mathbf{p}$ value \\
\hline \multicolumn{7}{|l|}{ Haplotype } \\
\hline ACC & $65(44.5)$ & $25(20.2)$ & 0.00247 & $20(31.2)$ & $5(8.3)$ & 0.00903 \\
\hline ATA & $77(52.8)$ & 97 (78.2) & 0.04333 & $44(68.8)$ & $53(88.4)$ & 0.35616 \\
\hline GCC & $4(2.7)$ & $2(1.6)$ & 0.54022 & $0(0)$ & $2(3.3)$ & 0.14751 \\
\hline \multicolumn{7}{|l|}{ Genotype } \\
\hline ACCIACC & $19(26.0)$ & $2(3.2)$ & 0.00161 & I (3.I) & I (3.3) & 0.96417 \\
\hline ACC/ATA & $27(37.0)$ & $21(33.9)$ & 0.79480 & $18(56.3)$ & $3(10.0)$ & 0.00578 \\
\hline ATA/ATA & $23(31.5)$ & 37 (59.7) & 0.04243 & $13(40.6)$ & $24(80.0)$ & 0.11117 \\
\hline GCC/ACC & $0(0)$ & $0(0)$ & - & $0(0)$ & $0(0)$ & - \\
\hline GCC/ATA & $4(5.5)$ & $2(2.2)$ & 0.54437 & $0(0)$ & $2(6.7)$ & 0.15076 \\
\hline GCC/GCC & $0(0)$ & $0(0)$ & - & $0(0)$ & $0(0)$ & - \\
\hline
\end{tabular}

Note: Bold letters/numbers represent statistical significance $(p<0.05)$.

Abbreviations: PSL-res., prednisolone responder; PSL-non., prednisolone nonresponders; Elt-res., eltrombopag responder; Elt-non., eltrombopag nonresponder; other abbreviations: see Table 2. 
patients with ITP and healthy controls. The frequency of the TGF $-\beta_{1}+869 \mathrm{C} / \mathrm{C}$ genotype was significantly lower in patients with ITP than in healthy controls. TGF- $\beta_{1}$ is produced by dendritic cells and T-cells, and it plays important roles in regulating immune function. ${ }^{43}$ Serum TGF- $\beta_{1}$ concentration is decreased in systemic lupus erythematosus (SLE). ${ }^{44,45}$ Moreover, mice deficient in TGF- $\beta_{1}$ exhibit enhanced production of autoantibodies, which could be related to the pathology of SLE. ${ }^{46}$ However, the relationship between ITP and polymorphisms in TGF- $\beta_{1}$ is not well defined, because there are few studies in the literature assessing TGF- $\beta_{1}$ in ITP patients. ${ }^{24,28,30}$ The TGF- $\beta_{1}$ polymorphism might be useful as a predictor of radiographic progression but further investigation is needed into the feasibility of this.

IL-10 is an anti-inflammatory cytokine produced mainly by Th2 cells and a variety of other cells, including Th1 and Th17 cells, B cells, and macrophages. ${ }^{47,48}$ Serum concentrations of IL-10 are elevated in the serum of patients with ITP compared with those in healthy individuals. ${ }^{32}$ Furthermore, IL-10 has been reported to affect immunological modulation in ITP $^{49,50}$ and might, therefore, be involved in the pathophysiology of ITP. ${ }^{26,32,38}$ In this study, however, we observed no significant differences in IL-10 genotypes in ITP patients and healthy controls. This discrepancy between studies may be related to ethnic factors. Saitoh et $\mathrm{al}^{31}$ reported that Japanese patients with ITP did not differ significantly from healthy controls with respect to polymorphisms in IL-10.

In the present study, we investigated the relationship between such polymorphisms and therapeutic responses to PSL and eltrombopag in patients with ITP. Patients who responded to PSL had higher frequencies of IL-10 -592 C/ $\mathrm{C}$ and $-819 \mathrm{C} / \mathrm{C}$ genotypes compared with nonresponders. Similarly, PSL responders had a lower frequency of the IL-10 -592 A/A and -819 T/T genotypes than responders. Other reports have described a relationship between IL-10 -592 A/A genotype and ITP severity. ${ }^{31,35}$ Our results partly support these previous reports. In the present study, we analyzed the IL-10 promoter polymorphism $(-1082,-819,-592)$ haplotypes ACC, ATA, and GCC (Table 5). PSL nonresponders had a lower frequency of the ACC/ATA genotype and a higher frequency of the ATA/ATA genotype. These results suggested that presence of the ATA haplotype and absence of the ACC haplotype were associated with response to PSL or ITP severity, which is similar to some previously reported studies. ${ }^{31,32,35}$ It is reported that IL-10 itself participates in reactivity to steroid in a murine model of ITP. ${ }^{47}$

Eltrombopag is a well-established treatment for ITP and is increasingly used in second-line management. ${ }^{17,19,51,52}$ However, the relationship between eltrombopag and cytokine gene polymorphisms has yet been reported, which we addressed in the present study. A total of 62 patients were treated with eltrombopag; 32 patients responded and $30 \mathrm{did}$ not. Eltrombopag responders had higher frequencies of the IL$10-819 \mathrm{C} / \mathrm{T}$ and $-592 \mathrm{C} / \mathrm{A}$ genotypes than the nonresponders. Furthermore, the IL-10 ACC/ATA genotype was significantly more common in eltrombopag responders. Thus, the results of IL-10 haplotype and genotype analysis did not always match in terms of responses to PSL and eltrombopag therapy. Eltrombopag is a second-line therapy used in patients who do not respond to PSL. ${ }^{17-19}$ However, the differences in IL-10 haplotypes and genotypes between eltrombopag responders and nonresponders are very interesting. It will be useful to determine the eltrombopag effect ITP patients. In addition, eltrombopag responders exhibited a higher frequency of the TGF- $\beta_{1}$ T/C genotype than nonresponders and a lower frequency of the T/T genotype. TGF- $\beta_{1}$ plays important roles in regulating immune function. ${ }^{43}$ We previously reported that TGF- $\beta_{1}$ and soluble cytotoxic T-lymphocyte-associated antigen 4 (sCTLA-4) levels are increased in eltrombopag-exposed patients with ITP. ${ }^{53}$ Our previous results suggested that eltrombopag partly modulates some immune responses through TGF- $\beta_{1}$ and sCTLA- 4 . TGF- $\beta_{1}$ plays an important role in the induction of tolerance by regulatory $\mathrm{T}$ cells in ITP. ${ }^{43,53,54}$ Further studies are needed to determine the clinical significance of polymorphisms in TGF- $\beta_{1}$ and immune modulation of eltrombopag.

This study had some limitations. First, the samples were obtained from a single facility and thus our data are probably not representative of the Japanese ITP population. Second, eltrombopag is only a second-line treatment. Finally, we did not define the relationship between polymorphisms in cytokine-encoding genes and TRAs other than eltrombopag in this study. Therefore, we do not know whether all TRAs are directly linked to such polymorphisms in patients with ITP. Prospective studies are needed to confirm the observations from this study.

\section{Conclusions}

In this study, we showed that the TGF- $\beta_{1}+869 \mathrm{C} / \mathrm{C}$ genotype might be related to ITP in Japanese patients with ITP. The IL-10 $-592 \mathrm{C} / \mathrm{C}$ and A/A, $-819 \mathrm{C} / \mathrm{C}$ and $\mathrm{T} / \mathrm{T}$, and $(-1082,-819,-592)$ ATA/ATA genotypes may be 
associated with the response to PSL. Furthermore, the IL-10 $-592 \mathrm{C} / \mathrm{A},-819 \mathrm{C} / \mathrm{T}$, and $-1082,-819,-592 \mathrm{ACC} / \mathrm{ATA}$ genotypes and the TGF- $\beta_{1}+869 \mathrm{~T} / \mathrm{T}$ and $\mathrm{T} / \mathrm{C}$ genotypes might be linked to the response to eltrombopag. These results indicate that polymorphism analysis of the cytokineencoding genes could be useful in understanding PSL and eltrombopag responsiveness in Japanese patients with ITP.

\section{Acknowledgments}

This study was partly supported by a Grant (19K07948 to S.N.) from the Ministry of Education, Science or Culture of Japan. We thank Louise Adam, ELS (D) and Gillian Campbell, from Edanz Group (https://en-author-services. edanz.com/ac) for editing a draft of this manuscript.

\section{Author Contributions}

All authors made a significant contribution to the work reported, whether that is in the conception, study design, execution, acquisition of data, analysis and interpretation, or in all these areas; took part in drafting, revising or critically reviewing the article; gave final approval of the version to be published; have agreed on the journal to which the article has been submitted; and agree to be accountable for all aspects of the work.

\section{Disclosure}

The authors do not have any conflicts of interest to report in this work.

\section{References}

1. Cines DB, Blanchette VS. Immune thrombocytopenic purpura. $N$ Engl $J$ Med. 2002;346(13):995-1008. doi:10.1056/NEJMra010501

2. Rodeghiero F, Stasi R, Gernsheimer T, et al. Standardization of terminology, definitions and outcome criteria in immune thrombocytopenic purpura of adults and children: report from an international working group. Blood. 2009;113(11):2386-2393. doi:10.1182/blood-2008-07162503

3. Semple JW, Milev Y, Cosgrave D, et al. Differences in serum cytokines levels in acute and chronic autoimmune thrombocytopenic purpura: relationhip to platelet phenotype and antiplatelet T-cell reactivity. Blood. 1996;87(10):4245-4254. doi:10.1182/blood.V87.10.4245. bloodjournal87104245

4. Kuwana M, Kaburaki J, Ikeda Y. Autoreactive T cells to platelet GPIIb-IIIa in immune thrombocytopenic purpura: role in production of antiplatelet autoantibody. J Clin Invest. 1998;102(7):1393-1402. doi: $10.1172 / \mathrm{JCI} 4238$

5. Nomura S, Matsuzaki T, Ozaki Y, et al. Clincal significance of HLADRB1*0410 in Japanese patients with idiopathic thrombocytopenic purpura. Blood. 1998;91(10):3616-3622. doi:10.1182/blood. V91.10.3616

6. Kuwana M, Kaburaki J, Kitasato H, et al. Immunodominant epitopes on glycoprotein IIb-IIIa recognized by autoreactive T cells in patients with immune thrombocytopenic purpura. Blood. 2001;98(1):130-139. doi:10.1182/blood.V98.1.130
7. Zufferey A, Kapur R, Semple JW. Pathogenesis and therapeutic mechanisms in immune thrombocytopenia (ITP). J Clin Med. 2017;6(2):16. doi:10.3390/jcm6020016

8. Li J, Sullivan JA, Ni H. Pathophysiology of immune thrombocytopenia. Curr Opin Hematol. 2018;25(5):373-381. doi:10.1097/MOH.0000000000000447

9. Marini I, Backhoul T. Pathophysiol of autoimmune thrombocytopenia: current insight with a focus on thrombopoiesis. Hamostaseologie. 2019;39(3):227-237. doi:10.1055/s-0039-1678732

10. Cooper N. State of the art - how I manage immune thrombocytopenia. Br J Haematol. 2017;177(1):39-54. doi:10.1111/bjh.14515

11. Miltiadous $\mathrm{O}$, Hou M, Bussel JB. Identifying and treating refractory ITP: difficulty in diagnosis and role of combination treatment. Blood. 2020;135(7):472-490. doi:10.1182/blood.2019003599

12. Nomura S. Advances in diagnosis and treatment for immune thrombocytopenia. Clin Med Insight Blood Disord. 2016;9:15-22.

13. Bussel JB, Cheng G, Saleh MN, et al. Eltrombopag for the treatment of chronic idiopathic thrombocytopenic purpura. $N$ Engl $J$ Med. 2007;357(22):2237-2247. doi:10.1056/NEJMoa073275

14. Bussel JB, Kuter DJ, Pullarkat V, et al. Safty and efficacy of long-term treatment with romiplostim in thrombocytopenic patients with chronic ITP. Blood. 2009;113(10):2161-2171. doi:10.1182/ blood-2008-04-150078

15. Kuter DJ, Rummel M, Roccia R, et al. Romiplostim or standard of care in patients with immune thrombocytopenia. $N$ Engl $\mathrm{J} \mathrm{Med.}$ 2010;363(20):1889-1899. doi:10.1056/NEJMoa1002625

16. Cheng G, Saleh MN, Marcher C, et al. Eltrombopag for management of chronic immune thrombocytopenia (RAISE): a 6-month, randomized, Phase 3 study. Lancet. 2011;377(9763):393-402. doi:10.1016/ S0140-6736(10)60959-2

17. Taylor A, Westwood JP, Laskou F, McGuckin S, Scully M. Thrombopoietin receptor agonist therapy in thrombocytopenia: ITP and beyond. Br J Haematol. 2017;177(3):475-480. doi:10.1111/bjh.14564

18. Wong RSM, Saleh MN, Khelif A, et al. Safety and efficacy of long-term treatment of chronic/persistent ITP with eltrombopag: final results of the EXTEND study. Blood. 2017;130 (23):2527-2536. doi:10.1182/blood-2017-04-748707

19. Ghanima W, Cooper N, Rodeghiero F, Godeau B, Bussel JB. Thrombopoietin receptor agonists: tenyears later. Haematologica. 2019;104(6):1112-1123. doi:10.3324/haematol.2018.212845

20. Bax M, van Heemst J, Huizinga TWJ, Toes REM. Genetics of rheumatoid arthritis: what have we learned? Immunogenetics. 2011;63(8):459-466. doi:10.1007/s00251-011-0528-6

21. Bettinotti MP, Hartung K, Deicher H, et al. Polymorphism of the tumor necrosis factor beta gene in systemic lupus erythematosus; TNFB-MHC haplotypes. Immunogenetics. 1993;37(6):449-454. doi:10.1007/BF00222469

22. Vandevyver C, Raus P, Stinisen P, et al. Polymorphism of the tumor necrosis factor beta gene in multiple sclerosis and rheumatoid arthritis. Eur J Immunogenet. 1994;21(5):377-382. doi:10.1111/ j.1744-313X.1994.tb00208.x

23. Bidwell J, Keen L, Gallagher G, et al. Cytokine gene polymorphism in human disease: online databeses. Gene Immunol. 1999;1(1):3-19. doi:10.1038/sj.gene.6363645

24. Atabay B, Oren H, Irken G, et al. Role of transforming growth factor-beta 1 gene polymorphisms in childhood idiopathic thrombocytopenic purpura. J Pediatr Hematol Oncol. 2003;25(11):885-889. doi:10.1097/00043426-200311000-00012

25. Satoh T, Pandey JP, Okazaki Y, et al. Single nucleotide polymorphisms of the inflammatory cytokine genes in adults with chronic immune thrombocytopenic purpura. Br J Haematol. 2004;124 (6):796-801. doi:10.1111/j.1365-2141.2004.04843.x

26. Wu KH, Peng CT, Li TC, et al. Interleukin 4, interleukin 6 and interleukin 10 polymorphisms in children with acute and chronic immune thrombocytopenic purpura. Br J Haematol. 2005;128 (6):849-852. doi:10.1111/j.1365-2141.2005.05385.x 
27. Emmerich F, Bal G, Barakat A, et al. High-level serum B-cell activating factor and promorter polymorphisms in patients with idiopathic thrombocytopenic purpura. $B r \quad J$ Haematol. 2007;136 (2):309-314. doi:10.1111/j.1365-2141.2006.06431.x

28. Ma D, Zhu X, Zhao P, et al. Profile of Th17 cytokines (IL-17, TGF- $\beta$, IL-6) and Th1 cytokine (IFN- $\gamma$ ) in patients with immune thrombocytopenic purpura. Ann Hematol. 2008;87(11):899-904. doi:10.1007/ s00277-008-0535-3

29. Okulu E, Ileri T, Kosan Culha V, et al. The role of tumor necrosis factor-alpha $-308 \mathrm{G} / \mathrm{A}$ and transforming growth factor-beta 1-915 G/ $\mathrm{C}$ polymorphisms in childhood idiopathic thrombocytopenic purpura. Turk J Haematol. 2011;28(3):170-175. doi:10.5152/tjh.2011.50

30. Pehlivan M, Okan V, Sever T, et al. Investigation of TNF-alpha, TGF-beta 1, IL-10, IFN-gamma, MBL, GPIA, and IL1A gene polymorphisms in patients with idiopathic thrombocytopenic purpura. Platelets. 2011;22(8):588-595. doi:10.3109/09537104.2011.577255

31. Saitoh T, Kasamatsu T, Inoue M, et al. Interkeukin-10 gene polymorphism reflects the severity of chronic immune thrombocytopenia in Japanese patients. Int $J$ Lab Hematol. 2011;33(5):526-532. doi:10.1111/j.1751-553X.2011.01320.x

32. Tesse R, Del Vecchio GC, Demattia D, et al. Association of interleukin-(IL)10 haplotypes and serum IL-10 levels in the progression of childhood immune thrombocytopenic purpura. Gene. 2012;505(1):53-56. doi:10.1016/j.gene.2012.05.050

33. Zhao H, Zhang Y, Xiao G, et al. Interleukin-18 gene promoter-607 $\mathrm{A} / \mathrm{C}$ polymorphism and the risk of immune thrombocytopenia. Autoimmunity. 2014;47(7):478-481. doi:10.3109/ 08916934.2014.921812

34. Pavkovic M, Angelovic R, Popova-Simjanovska M, et al. Single nucleotide polymorphisms of the inflammatory xcytokine genes: interleukin-1B, tumor necrosis factor-A and tumor necrosis factor-B in adult patients with immune thrombocytopenia. Pril. 2015;36(1):109-115. doi:10.1515/prilozi-2015-0035

35. Ghannam DEI, Fawzy IM, Azmy E, Hakim H, Eid I. Relation of interleukin-10 promorter polymorphisms to ault chronic immune thrombocytopenic purpura in a cohort of Egyptian population. Immunol Invest. 2015;44(7):616-626. doi:10.3109/08820139.2015.1064948

36. Yadav DK, Tripathi AK, Kumar A, et al. Association of TNF- $\alpha-308$ $\mathrm{G}>\mathrm{A}$ and TNF- $\beta+252$ A.G genes polymorphisms with primary immune thrombocytopenia: a North Indian study. Blood Coagul Fibrinolysis. 2016;27(7):791-796. doi:10.1097/MBC.0000000000000492

37. Morgan DS, Afifi RA, EI-Hoseiny SM, Amin DG, Ibrahim SYG. The potential association of tumor necrosis factor- $\beta(252 \mathrm{G} / \mathrm{A})$ cytokine gene polymorphism with immune thrombocytopenic purpura among Egyptian children. Hematology. 2018;23(5):299-303. doi:10.1080/ 10245332.2017.1386429

38. Ou Y, Yang Y, Xiang X, Wu Y. Relationship between the IL-10 $(-1082 \mathrm{~A} / \mathrm{G})$ polymorphism and the risk of immune/idiopathic thrombocytopenic purpura: a meta-analysis. Cytokine. 2020;125:154820. doi:10.1016/j.cyto.2019.154820

39. AI-Samkari H, Kuter DJ. Immune thrombocytopenia in adults: modern approaches to diagnosis and treatment. Semin Thromb Hemost. 2020;46(3):275-288. doi:10.1055/s-0039-1700512
40. Provan D, Stasi R, Newland AC, et al. International consensus report on the investigation and management of primary immune thrombocytopenia. Blood. 2010;115(2):168-186. doi:10.1182/blood2009-06-225565

41. Neunert C, Noroozi N, Norman G, et al. Severe bleeding events in adults and children with primary immune thrombocytopenia: a systematic review. J Thromb Haemost. 2015;13(3):457-464. doi:10.1111/jth.12813

42. Tsujimoto S, Ozaki Y, Ito T, Nomura S. Usefukness of cytokine gene polymorphisms for the therapeutic choice in Japanese patients with rheumatoid arthritis. Int J Gene Med. 2021;14:131-139. doi:10.2147/ IJGM.S287505

43. Letterio JJ, Roberts AB. Regulation of immune responses by TGF- $\beta$. Annu Rev Immunol. 1998;16:137-161. doi:10.1146/annurev. immunol.16.1.137

44. Gualtierotti R, Biggioggero M, Penatti AE, Meroni PL. Updating on the pathogenesis of systemic lupus erythematosus. Autoimmun Rev. 2010;10(1):3-7. doi:10.1016/j.autrev.2010.09.007

45. Su DL, Lu ZM, Shen MN, Li X, Sun LY. Roles of pro- and anti-inflammatory cytokines in the pathogenesis of SLE. $J$ Biomed Biotechnol. 2012;2012:347141. doi:10.1155/2012/347141

46. Shull MM, Ormsby I, Kier AB, et al. Targeted disruption of the mouse transforming growth factor- $\beta 1$ gene results in multifocal inflammatory disease. Nature. 1992;359(6397):693-699. doi:10.1038/359693a0

47. Mosser DM, Zhang X. Interleukin-10: new perspectives on an old cytokine. Immunol Rev. 2008;226:205-218. doi:10.1111/j.1600065X.2008.00706.x

48. Tian G, Li JL, Wang DG, Zhou D. Targeting IL-10 in auto-immune diseases. Cell Biochem Biophys. 2014;70(1):37-49. doi:10.1007/ s12013-014-9903-x

49. Ma L, Liang Y, Fang M, et al. The cytokines (IFN-gamma, IL-2, IL-4, IL-10, IL-17) and Treg cytokine (TGF-beta1) kevels in adult with immune thrombocytopenia. Pharmazie. 2014;69(9):694-697.

50. Goelz N, Bosch AMS, Rand ML, et al. Increased levels of IL-10 and IL-1Ra counterbalance the proinflammatory cytokine pattern in acute pediatric immune thrombocytopenia. Cytokine. 2020;130:155078. doi:10.1016/j.cyto.2020.155078

51. Ma L, Simpson E, Li J, et al. $\mathrm{CD}^{+} \mathrm{T}$ cells are predominantly protective and required for effective steroid therapy in murine models of immune thrombocytopenia. Blood. 2015;126(2):247-256. doi:10.1182/blood-2015-03-635417

52. Gonzalez-Porras JR, Bastida JM. Eltrombopag in immune thrombocytopenia: efficacy review and update on drug safety. The Adv Drug Saf. 2018;9(6):263-285. doi:10.1177/2042098618769587

53. Fujita S, Nakanishi T, Yoshimura H, et al. TGF $\beta 1$ and sCTLA-4 levels are increased in eltrombopag-exposed patients with ITP. Thromb Res. 2012;130(3):415-419. doi:10.1016/j.thromres.2012.06.002

54. Bao W, Bussel JB, Heck S, et al. Improved regulatory T-cellactivity in patients with chronic immune thrombocytopenia treated with thrombopoietic agents. Blood. 2010;116(22):4639-4645. doi:10.1182/blood-2010-04-281717
Journal of Blood Medicine

\section{Publish your work in this journal}

The Journal of Blood Medicine is an international, peer-reviewed, open access, online journal publishing laboratory, experimental and clinical aspects of all aspect pertaining to blood based medicine including but not limited to: Transfusion Medicine; Blood collection, Donor issues, Transmittable diseases, and Blood banking logistics; Immunohematology; Artificial and alternative blood based therapeutics; Hematology; Biotechnology/nanotechnology of blood related medicine; Legal aspects of blood medicine; Historical perspectives. The manuscript management system is completely online and includes a very quick and fair peer-review system. Visit http://www.dovepress.com/testimonials.php to read real quotes from published authors. 